\title{
$\beta$-hCG levels in second trimester as a predictor of gestational hypertension and preeclampsia
}

\author{
Neha Rathore, Reema Khajuria, Rohini Jaggi* \\ Department of Obstetrics and Gynaecology, SMGS, GMC, Jammu, Jammu and Kashmir, India
}

Received: 13 December 2021

Accepted: 28 December 2021

\author{
*Correspondence: \\ Dr. Rohini Jaggi, \\ E-mail: rohiniabhishekanand@gmail.com
}

Copyright: (c) the author(s), publisher and licensee Medip Academy. This is an open-access article distributed under the terms of the Creative Commons Attribution Non-Commercial License, which permits unrestricted non-commercial use, distribution, and reproduction in any medium, provided the original work is properly cited.

\begin{abstract}
Background: Hypertensive disorders of pregnancy complicate up to $10 \%$ of pregnancies worldwide, and remain amongst the most significant and intriguing unsolved problems in obstetrics. The goal of this study is to test the hypothesis that women with high serum $\beta$-hCG levels in early pregnancy are at higher risk of developing gestational hypertension and preeclampsia.

Methods: This is a prospective study done in 200 women between 13 and 20 weeks of gestation, selected randomly for this study. Serum $\beta$-hCG estimation was done by Sandwich chemiluminescence immunoassay method and calculated in multiple of median (MOM). They were followed till delivery for development of gestational hypertension and preeclampsia. Results were analysed statistically.

Results: Out of 200 cases, $43(21.5 \%)$ cases developed PIH. $\beta$-hCG levels were considered raised if the levels were $>2$ MOM. Out of 39 cases with beta HCG levels >2 MOM, $32(82.1 \%)$ developed PIH whereas $7(17.9 \%)$ remain normotensives against. Also, higher levels of beta HCG are associated with increased severity of PIH (p<0.000). The sensitivity was $82 \%$, specificity was $93.2 \%$ and positive predictive value was $74.3 \%$.

Conclusions: The study conclude that elevated serum $\beta$-hCG levels in women with second trimester pregnancy indicates increased risk of gestational hypertension and preeclampsia and raised $\beta$-hCG levels are associated with severity of disease
\end{abstract}

Keywords: Human chorionic gonadotrophin, Placenta, Gestational hypertension and preeclampsia, Second trimester pregnancy, Sensitivity and specificity

\section{INTRODUCTION}

Hypertensive disorders during pregnancy remain amongst the most significant and intriguing unsolved problems in obstetrics, complicating up to $10 \%$ of pregnancies worldwide. ${ }^{1}$ The incidence of preeclampsia in India is about $8-10 \%$ and maternal mortality due to preeclampsia reported to be $8 \% .^{2}$ It also constitute one of the greatest causes perinatal and neonatal morbidity and mortality of about $10 \%$ worldwide. $^{2-4}$

Gestational hypertension along with its sequelae that is preeclampsia and eclampsia can be best described as a human pregnancy-specific syndrome. ${ }^{5,6}$ It affect virtually every organ system and widely varies in its clinical phenotypic expression. ${ }^{6}$

Pathogenesis of preeclampsia is complicated and has not been fully elucidated. It is currently believed to result from a combination of immunologic, environmental, and genetic factors. These factors lead to the failure of normal trophoblastic invasion and remodeling of the uterine spiral arteries leading to impaired placentation. This has been considered as one of the initial events in the disease process. $^{7,8}$ It results in endothelial dysfunction with associated vasospasm. ${ }^{9}$ Vasospasm results in vascular 
damage and local hypoxia leading to hemorrhage, necrosis and end organ damage and therefore involves multiple organ systems. It can decrease utero-placental blood flow of about $30-40 \%$ as compare to normal pregnancy. ${ }^{10}$

Because trophoblasts play a vital role in the development of preeclampsia, there are few placental hormones changes in maternal circulation. This indicates a derangement of placental function long before the onset of preeclampsia and have been proposed as early predictors of it. ${ }^{2}$ Considerable evidence suggests an association between serum hCG levels and preeclampsia. ${ }^{11-14}$

Human chorionic gonadotrophin (hCG), is a glycoprotein, with molecular weight of 36,000 to $40,000 \mathrm{Da}$. produced by the syncytiotrophoblast of the placenta ${ }^{1}$. It is believed that human chorionic gondotropin (hCG) preserves sufficient uteroplacental perfusion during the entire gestation period by an endothelial-independent mechanism. ${ }^{15}$

The specific mechanism for maternal serum $\beta$-hCG level elevation in pregnancies with adverse outcome is unknown. But hypertensive disorder leading to placental immaturity and utero placental under perfusion results in placental hypoxia and placental vascular changes. This causes reactive hyperplasia of cyto-trophoblastic cells which may be responsible for increased production of $\beta$ hCG hormone. ${ }^{16}$ As the changes in $\beta$-hCG levels can reflect the placental reaction to preeclampsia, we are encouraged to determine the association between serum $\beta$ hCG level and preclampsia in second trimester of pregnancy.

The present study is, therefore, one of the efforts to predict preeclampsia by measuring serum $\beta$-hCG levels which is readily acceptable and non-invasive methods.

\section{METHODS}

The present study is prospective observational study conducted in the postgraduate department of obstetrics and gynaecology, SMGS hospital, government medical college, Jammu, over a period of one year i.e., from October 2018-September 2019 after getting approval from institutional ethical committee.

\section{Inclusion criteria}

The 200 pregnant, normotensive, nonproteinuric women with singleton pregnancies coming to ANC clinics were selected randomly between the gestational age of 13-20 weeks irrespective of parity were included in the study.

\section{Exclusion criteria}

Women with multiple pregnancy, congenital malformation, essential hypertension, diabetes mellitus, molar pregnancy and history of down syndrome were excluded from the study.
All the subjects were informed about the study and informed consent was taken before they were enrolled in the study.

Women were subjected to detailed history including age, parity, height, pre-pregnancy weight, and weight at time of blood collection. Gestational age was calculated from reliable last menstrual history and early ultrasonography. Family history, past obstetric history, past medical history, smoking habits, medical historyy of first-degree family members was taken.

Systemic examination with special reference to edema, blood pressure and gestational week was carried out and routine antenatal investigations were done.

Venous blood sample $(3 \mathrm{ml})$ was collected and estimation of serum $\beta$-hCG was done by chemiluminescent microparticle Immunoassay (CMIA) method. The $\beta$-hCG levels were expressed as multiples of median (MOM), calculated from median of the diagnostic test employed for the current study (ARCHITECT 7K78 total $\beta$-hCG reagent kit). Serum $\beta$-hCG was considered raised if levels were $>2$ MOM.

All patients were followed up in antenatal clinic and examined 4 weeks to 28 weeks, fortnightly up to 34 weeks and thereafter weekly till delivery and were observed for development of gestational hypertension and preeclampsia. At each antenatal visit, blood pressure, pedal edema was noted and urine for albumin was performed. Definitions were used for gestational hypertension and preeclampsia.

Gestational hypertension is defined as systolic $\mathrm{BP} \geq 140$ $\mathrm{mmHg}$ or diastolic $\mathrm{BP} \geq 90 \mathrm{mmHg}$ occurring on two or more occasions 6hrs apart after 20 weeks of gestation for first time during pregnancy without proteinuria.

Preeclampsia is defined as: Mild preeclampsia if $\mathrm{BP} \geq 140 / 90 \mathrm{mmHg}$ after 20 weeks of gestation and proteinuria $\geq 300 \mathrm{mg} / 24$ hours or $\geq 1+$ dipstick. Severe preeclampsia if $\mathrm{BP} \geq 160 / 110 \mathrm{mmHg}$ and proteinuria $\geq 5$ $\mathrm{g} / 24$ hours or $\geq 3+$ dipstick.

Results so obtained were evaluated and analyzed statistically. Chi-square test was applied. Odd's ratio with $95 \%$ confidence interval was calculated and reported. A $\mathrm{p}<0.05$ was considered statistically significant.

\section{RESULTS}

Out of 200 pregnant women who were enrolled in this study, (21.5\%) developed hypertension while 157 (78.5\%) remained normotensive.

Table 1 shows distribution of patients according to different age groups and their association with hypertension. Maximum number of patients i.e., $89.8 \%$ among normotensive and $86 \%$ among hypertensives 
belonged to age group of 21-30 year. Mean \pm SD was $25.52 \pm 3.45$ and $24.60 \pm 3.02$ of normotensive and hypertensive respectively. There was no significant association seen between age and PIH.

Table 1: Age wise distribution of patients and its association with hypertension.

\begin{tabular}{|llll|}
$\begin{array}{l}\text { Age } \\
\text { group } \\
\text { (Years) }\end{array}$ & $\begin{array}{l}\text { No. of } \\
\text { patients }\end{array}$ & $\begin{array}{l}\text { Normotensive } \\
(\%)\end{array}$ & $\begin{array}{l}\text { Hypertensive } \\
(\%)\end{array}$ \\
\hline $\mathbf{2 0}$ & 11 & $8(5.5)$ & $3(7)$ \\
\hline $\mathbf{2 1 - 3 0}$ & 178 & $141(89.8)$ & $37(86)$ \\
\hline $\mathbf{3 0}$ & 11 & $8(5.5)$ & $3(7)$ \\
\hline Total & 200 & 157 & 43 \\
\hline
\end{tabular}

Chi square $=0.488$, deg of freedom $1, p=0.769$

Table 2: Association of parity with PIH.

\begin{tabular}{|llll|} 
Parity & $\begin{array}{l}\text { No. of } \\
\text { patients } \\
(\%)\end{array}$ & $\begin{array}{l}\text { Normotensive } \\
(\%)\end{array}$ & $\begin{array}{l}\text { Hypertensive } \\
(\%)\end{array}$ \\
\hline P0 & $122(61)$ & $89(56.7)$ & $33(76.7)$ \\
\hline P1 & $54(27)$ & $48(30.6)$ & $6(14)$ \\
\hline$\geq \mathbf{P 2}$ & $24(12)$ & $20(12.7)$ & $4(9.3)$ \\
\hline Total & 200 & 157 & 43 \\
\hline
\end{tabular}

Chi square $=7.026$, degree of freedom $1, \mathrm{p}<0.05$

Table 2 shows distribution of cases according to the different parity and its association with hypertension. It was observed that maximum number of patients i.e. $56.7 \%$ among the normotensive group were nulliparous whereas among the hypertensives, $76.7 \%$ patients were nulliparous. It shows that primi gravidas had increased risk of developing pregnancy induced hypertension as compared to multigravidas and this association is statistically significant.

Table 3: Association between $\beta$-hCG (MOM) and PIH.

\begin{tabular}{|lll|l|}
$\begin{array}{l}\boldsymbol{\beta} \text {-hCG } \\
(\mathrm{MOM})\end{array}$ & $\begin{array}{l}\text { No. of } \\
\text { patient } \\
(\%)\end{array}$ & $\begin{array}{l}\text { Normotensive } \\
(\%)\end{array}$ & $\begin{array}{l}\text { Hypertensive } \\
(\%)\end{array}$ \\
\hline $\mathbf{3}$ & $\begin{array}{l}\mathbf{\%} \\
(80.5)\end{array}$ & $\begin{array}{l}150 \\
(93.2)\end{array}$ & $\begin{array}{l}11 \\
(6.8)\end{array}$ \\
\hline $\mathbf{2}$ & 39 & 7 & 32 \\
& $(19.5)$ & $(17.9)$ & $(82.1)$ \\
\hline Total & 200 & 157 & 43 \\
\hline
\end{tabular}

Chi square $=105.24, p=0.000$

As shown in Table 3, out of total 200 patients, $161(80.5 \%)$ had $\beta$-hCG levels $\leq 2$ MOM, whereas 39 (19.5\%) patients had values >2 MOM. Out of 39 patients with $\beta$-hCG >2 MOM, 32 (82.1\%) developed PIH whereas only 7 (17.9\%) remained normotensive. And out of 161 patients with $\beta$ hCG $\leq 2$ MOM, only 11 (6.8\%) patients developed PIH. This difference was highly significant with $\mathrm{p}=0.000$. Serum $\beta$-hCG had a sensitivity of $82 \%$, specificity of
$93.2 \%$, positive predictive value of $74.3 \%$, negative predictive value of $95.5 \%$ and accuracy of $91 \%$.

Table 4 shows association of $\beta$-hCG levels with the severity of PIH. It was observed that there was a significant association between $\beta$-hCG levels and PIH severity with $\mathrm{p}=0.000$. On logistic regression analysis, each unit of increase in $\beta$-hCG increased 3.65 odds of having hypertension and result was statistically significant.

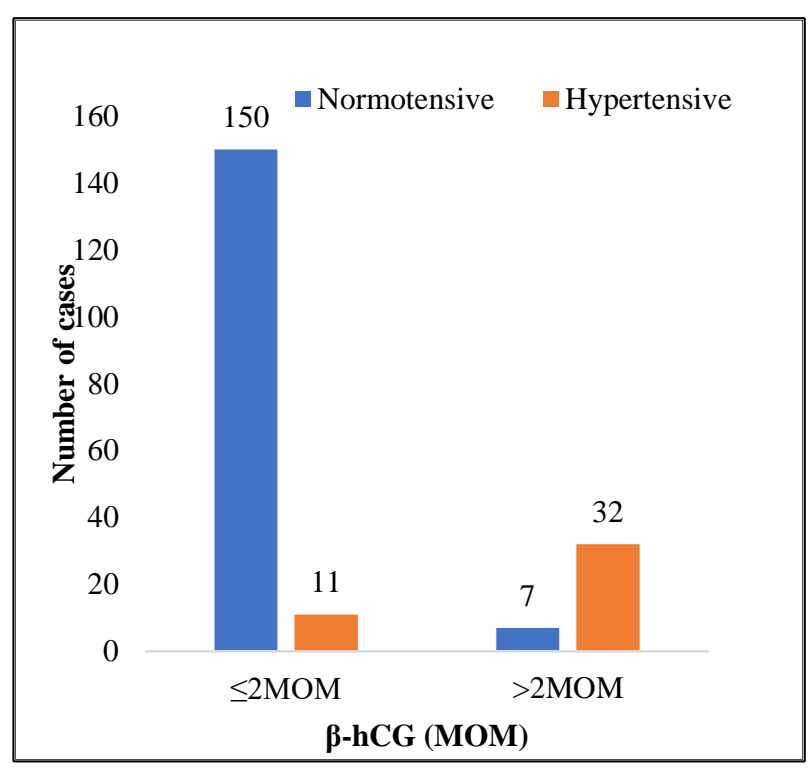

Figure 1: Association between $\beta$-hCG (MOM) and PIH.

Table 4: Association between $\beta$-hCG and PIH severity.

\begin{tabular}{|c|c|c|c|c|c|}
\hline $\begin{array}{l}\boldsymbol{\beta} \text {-hCG, } \\
\text { (mIU) }\end{array}$ & $\mathbf{N}$ & $\begin{array}{l}\text { Normo } \\
\text { tensive } \\
(\%)\end{array}$ & $\begin{array}{l}\text { GH } \\
(\%)\end{array}$ & $\begin{array}{l}\text { Mild } \\
\text { PE } \\
(\%)\end{array}$ & $\begin{array}{l}\text { Severe } \\
\text { PE } \\
(\%)\end{array}$ \\
\hline$<30000$ & 62 & $\begin{array}{l}62 \\
(100)\end{array}$ & - & - & - \\
\hline $\begin{array}{l}30000- \\
40000\end{array}$ & 51 & $\begin{array}{l}48 \\
(94.1)\end{array}$ & $\begin{array}{l}3 \\
(5.9)\end{array}$ & - & - \\
\hline $\begin{array}{l}41000- \\
50000\end{array}$ & 32 & $\begin{array}{l}27 \\
(84.4)\end{array}$ & $\begin{array}{l}4 \\
(12.5)\end{array}$ & $\begin{array}{l}1 \\
(3.1)\end{array}$ & - \\
\hline $\begin{array}{l}51000- \\
60000\end{array}$ & 15 & $\begin{array}{l}12 \\
(80)\end{array}$ & $\begin{array}{l}2 \\
(13.3)\end{array}$ & $\begin{array}{l}1 \\
(6.7)\end{array}$ & - \\
\hline $\begin{array}{l}61000- \\
70000\end{array}$ & 12 & $6(50)$ & $\begin{array}{l}4 \\
(33.3)\end{array}$ & $\begin{array}{l}2 \\
(16.7)\end{array}$ & - \\
\hline $\begin{array}{l}\text { 71000- } \\
80000\end{array}$ & 8 & $\begin{array}{l}1 \\
(12.5)\end{array}$ & $2(25)$ & $4(50)$ & $\begin{array}{l}1 \\
(12.5)\end{array}$ \\
\hline $\begin{array}{l}81000- \\
90000\end{array}$ & 7 & $\begin{array}{l}1 \\
(14.3)\end{array}$ & $\begin{array}{l}2 \\
(28.6)\end{array}$ & $\begin{array}{l}2 \\
(28.6)\end{array}$ & $\begin{array}{l}2 \\
(28.6)\end{array}$ \\
\hline $\begin{array}{l}91000- \\
100000\end{array}$ & 6 & - & - & $\begin{array}{l}1 \\
(16.7)\end{array}$ & $\begin{array}{l}5 \\
(83.3)\end{array}$ \\
\hline$>100000$ & 7 & - & - & $\begin{array}{l}1 \\
(14.3)\end{array}$ & $\begin{array}{l}6 \\
(85.7)\end{array}$ \\
\hline Total & 200 & 157 & 17 & 12 & 14 \\
\hline
\end{tabular}

Chi square $=219.47, \mathrm{p}=0.000$ 


\section{DISCUSSION}

Hypertensive disorders of pregnancy are one of the greatest and dangerous complication causing premature delivery, fetal growth retardation, abruptio placentae, fetal death and maternal morbidity and mortality. Pre-eclampsia is a complex condition, which cannot be attributed to any single cause. Present study was conducted to analyse relationship of maternal serum $\beta$-hCG levels during second trimester and subsequent development of hypertension. Our study also analysed the association of high levels of beta HCG with severity of hypertensive disorders in pregnancy.

In the present study, among 200 women who completed the study, 157 patients remained normotensive whereas 43 patients developed hypertension. This gives prevalence rate of $21.5 \%$. In the study done by Vidyabati et al among 164 women who completed the study, 29 (17.7\%) developed hypertension. ${ }^{17}$ Another study was done by Satyanarayan et al. in which 200 women were enrolled. 174 women completed the study out of which $21(10.8 \%)$ developed hypertension. ${ }^{18}$

Most of the patients in our study were in age group of 2130 years i.e., $178(89 \%)$, which is the peak reproductive age group in our country. The $141(89.8 \%)$ patients in the normotensive group and $37(86 \%)$ in hypertensive group were in this age interval. Therefore, association between age and PIH is not statistically significant with $\mathrm{p}=0.769$. Therefore it is observed in our study that age does not have any significant role in development of hypertension in pregnancy. Our results are consistent with findings of studies done by various authors in which no significant association between age and hypertensive disorder of pregnancy was observed. ${ }^{2,17,19}$

In our study, out of 43 patients in hypertensive group, 33 $(76.7 \%)$ were primigravidas whereas only $23.3 \%$ were multigravidas. This difference was stastically significant $(\mathrm{p}<0.05)$ which indicates that primigravidas had increased risk of developing pregnancy induced hypertension as compared to multigravidas. Our results are consistent with observations of Yadav et al in which, 93\% of women in normotensive group (control) and $73.3 \%$ in hypertensive group (cases) were primigravida. ${ }^{20}$ This difference was statistically significant $(\mathrm{p}<0.001)$. Kour et al in their study found no significant association between parity and PIH but occurrence of PIH was more among primiparas. ${ }^{21}$

In the present study, among 200 patients analysed, value of serum $\beta$-hCG ranged from $7248 \mathrm{mIU} / \mathrm{mL}$ to 118932 $\mathrm{mIU} / \mathrm{mL}$. It was observed that incidence of PIH with elevated $\mathrm{b}-\mathrm{hCG}>2 \mathrm{MOM}$ was $74.4 \%$ when compared to women $\leq 2$ MOM i.e., $25.5 \%$.

Our results are consistent with Kour et al who observed that among cases with $\beta$-hCG values >2 MOM, 83.33\% developed $\mathrm{PIH}$, and only $16.66 \%$ remained normotensive whereas among cases with $\beta$-hCG values <2 MOM, only
$1.2 \%$ developed PIH $(\mathrm{p}<0.001) .{ }^{21}$ Therefore patients with higher levels of beta HCG are associated with increased risk of developing PIH. Our results are also supported by the findings of prospective study conducted by Sharma et al. Out of 100 cases in study group, 17 cases had level of serum $\beta$-hCG $>2$ MOM and among these 17 cases, $82.35 \%$ developed PIH. Out of 50 cases in control group, 4 cases had level of serum $\beta$-hCG >2 MOM and none of them developed PIH. ${ }^{16}$

Kulkarni et al conducted a study, the results of which are consistent with those of present study. According to this, it was evident that those pregnant women having very high serum beta HCG level $>2 \mathrm{MOM}$ and $\geq 40,000 \mathrm{mIU} / \mathrm{ml}$, the incidence of PIH was more and sensitivity and specificity of $\beta$-hCG is $96 \%$ and $76 \%$ respectively. ${ }^{6}$ Rajesh et al also found that $\beta$-hCG levels (Mean \pm SD) were higher $(69808.66 \pm 54764.7$ vs. $38126.49 \pm 97419.2 ; \mathrm{p}<0.28)$ in subjects who developed gestational hypertension with sensitivity of $75 \%$, specificity of $72.5 \%$ and accuracy of $72.8 \%{ }^{2}$ Many other authors also have shown significant association between high levels of beta HCG and hypertensive disorders in pregnancy. ${ }^{2,19,22,23}$

\section{Table 5: Comparison sensitivity and specificity of $\beta$ -} hCG.

\begin{tabular}{|llll|}
\hline Studies & Sensitivity & Specificity & PPV \\
\hline Kaur et al & 90.91 & 59 & 19 \\
\hline Kulkarni et al & 96 & 76 & - \\
\hline Rajesh et al & 75 & 72.5 & 32.1 \\
\hline Present study & 82 & 93.2 & 74.3 \\
\hline
\end{tabular}

Some studies observed that low hCG concentrations in early pregnancy are associated with increased risk of preeclampsia. It might be attributed to impaired proliferation or invasion of trophoblast cells causing low bHCG concentrations. Thus it hypothesizes that, maternal $\beta$-hCG concentrations were inversely associated with the risk of pre-eclampsia in a dose-dependent manner and may be a useful predictor for pre-eclampsia. ${ }^{24,25}$

In the present study, we have also seen the correlation of beta HCG levels with the severity of PIH. It was observed that increasing beta HCG levels (in $\mathrm{mIU} / \mathrm{ml}$ ) showed a direct association with the severity of PIH and this association was statistically highly significant with $\mathrm{p}<0.05$.

Our results are similar to those of study done by Balvinder et al, which showed significantly higher HCG levels in severe pre- eclampsia $38916.48 \pm 8723.34 \mathrm{mIU} / \mathrm{ml}$ than mild preeclampsia $(16786.29 \pm 5345.113 \mathrm{mIU} / \mathrm{ml})$, showing increasing HCG levels associated with increase in severity of disease. ${ }^{26}$ Similar results were shown by Begum et al in which they observed higher $\beta$-hCG levels in severe preeclampsia as compared in mild preeclampsia. ${ }^{27}$ Kour et al also concluded that there was a positive correlation between the absolute beta HCG levels and the severity of PIH. ${ }^{21}$ In contrast Aquilina et al, 
demonstrated no correlation between levels of serum $\beta$ hCG and severity of pre-eclampsia. ${ }^{28}$

The results of the present study showed that the $\beta$-hCG level in preeclampsia tends to increase due to disorder in the activity of placental cells leading to placental perfusion disorder and damaging to throphoblastic cells. One promising hypothesis is that, impaired placental development leads to fetoplacental hypoxia as fetal demands increase during the second and third trimesters. Hypoxia may initiate an angiogenic response that leads to high maternal serum concentrations of $\beta$-hCG, sFlt-1, sendoglin and other angiogenic markers. Some of these may be the causes of maternal hypertension and proteinuria that characterizes pre-eclampsia. ${ }^{29,30,31}$ Therefore, measuring the $\beta$-hCG level may help in early diagnosis of the disease as well as may be an indicator of the severity of disease.

\section{Limitations}

The sample size for this study being small, necessitate the need of further large-scale studies considering the importance of $\beta$-hCG in PIH prediction.

\section{CONCLUSION}

It is concluded from our study that abnormally elevated $\beta$ hCG levels in early second trimester i.e., 13-18 weeks of pregnancy are good non-invasive predictors of hypertensive disorders of pregnancy. Therefore, women with raised $\beta$-hCG should be carefully followed up for subsequent development of hypertension, so that these women can be referred to a tertiary care centre for better management.

Funding: No funding sources Conflict of interest: None declared

Ethical approval: The study was approved by the Institutional Ethics Committee

\section{REFERENCES}

1. Cunningham LB, Spong DH, Casey. Hypertensive disorders chapter 40, William's obstetrics $24^{\text {th }}$ edition, Mc Graw Hill Education, New York. 2014;728-9.

2. Rajesh A, Vandana M. Serum beta hCG in early second trimester as a predictor of gestational hypertension. Int $\mathbf{J}$ Reprod Contracept Obstet Gynecol. 2018;7(6):2355-9.

3. Daskalakis G, Papapanagiotou A. Serum Markers for the Prediction of Preeclampsia. J Neurol Neurophysiol. 2015;6:264.

4. Yu CK, Smith GC, Papageorghiou AT. An integrated model for the prediction of pre-eclampsia using maternal factors and uterine artery Doppler velocimetry in unselected low-risk women. Am J Obstet Gynecol. 2006;195(1):330.
5. Khan K, Say L, Gulmezoglu AM. WHO analysis of causes of maternal death: A systematic review. Lancet. 2006;367:1066-74.

6. Kulkarni N, Bansal R, Pawar P. Serum Beta HCG and uterine artery Doppler studies in second trimester to predict preeclampsia and eclampsia. Int $\mathrm{J}$ Reprod Contracept Obstet Gynecol. 2018;7(5):1924-8.

7. Kharfi A, Giguere Y, Sapin V. Trophoblastic remodeling in normal and preeclamptic pregnancies: implication of cytokines. Clin Biochem. 2003;36:32331.

8. Hsu CD, Chan DW, Iriye B. Elevated serum human chorionic gonadotropin as evidence of secretory response in severe preeclampsia. Am $\mathbf{J}$ Obstet Gynecol. 1994;170:1135-8.

9. Brodszki J, Lanne T, Laurini R. Vascular mechanical properties and endothelial function in pre-eclampsia with special reference to bilateral uterine artery notch. Acta Obstet Gynecol Scand. 2008;87:154-62.

10. Chavarria ME, Lara-Gonzalez L. Prostacycline thromboxane, early changes in pregnancies that are complicated by preeclampsia. Am J Obstet Gynecol. 2003;88:986-92.

11. Adnan MN, Ashour MB, Ellice S. The value of elevated second trimester beta HCG in predicting development of preeclampsia. Am J Obstet Gynecol. 1997;176(2):438-42.

12. Anneli MP, Anna LH, Olli JV. Midtrimester Nterminal proatrial. Natriuretic peptide, free beta hCG, and alpha-fetoprotein in predicting Preeclampsia. Obstet Gynecol. 1998;91:940-4.

13. Muller F, Savey L, Fiblec LB. Maternal serum HCG Levels at fifteen weeks is a predictor of preeclampsia. Am J Obstet Gynecol. 1996;175:37-40

14. Onderoglu LS, Kabukçu A. Elevated second trimester human chorionic gonadotropin level associated with adverse pregnancy outcome. Int J Obstet Gynecol. 1997;56:245-9.

15. Hermsteiner M, Zoltan DR, Kunzel W. Human chorionic gonadotropin attenuates the vascular response to angiotensin II. Eur J Obstet Gynecol Reprod Biol. 2002;102:148-54.

16. Sharma P, Maheshwari S, Barala S. Correlation between second trimester beta human chorionic gonadotropin levels and pregnancy outcome in high risk group. Int J Reprod Contracept Obstet Gynecol. 2016;5(7):2358-61.

17. Vidyabati RK, Davina H, Singh NK, Gynaehswar $\mathrm{SW}$. Serum $\beta \mathrm{hCG}$ and lipid profile in second trimester as predictors of pregnancy induced hypertension. J Obstet Gynecol India. 2010;60(1):4450.

18. Satyanarayan K, Sawhney H, Vasishta K. Association between second trimester maternal serum hCG levels and PIH. J Obst Gyn India. 2001;51:85-8.

19. Gokdeniz R, Perez R, David M. Elevated serum HCG levels in severe preeclampsia. Turk J Med Sci. 2000;30:43-5.

20. Yadav S, Gupta S, Chandra. Correlation of elevated levels of maternal serum beta HCG in pregnancy 
induced hypertension and pregnancy outcomes in these petients. Indian J Pathol Microbiol. 1997;40(3):345-9.

21. Kaur G, Jain V, Mehta S. Prediction of PIH by Maternal Serum Beta HCG Levels in the Second Trimester (13-20 weeks) of Pregnancy. J Obstet Gynecol India. 2012;62:32-4.

22. Roiz-Hernandez J, de Cabello-Martinez J, Fernandez Mejia M. Human chorionic gonadotropin levels between 16 and 21 weeks of pregnancy and prediction of pre-eclampsia. Int J Gynaecol Obstet. 2006;92:1015.

23. Sorensen TK, Williams MA, Zingheim RW. Elevated second trimester HCG and subsequent pregnancy induced hypertension. Am J Obstet Gynecol. 1993;169:834-8.

24. Asvold BO, Vatten LJ, Tanbo TG, Eskild A. Concentrations of human chorionic gonadotrophin in very early pregnancy and subsequent pre-eclampsia. Human Reprod. 2014;29(6):1153-60.

25. Keikkala E, Vuorela P, Laivuori H, Romppanen J, Heinonen S, Stenman UH. First trimester hyperglycosylated human chorionic gonadotrophin in serum-A marker of early-onset preeclampsia. Placenta. 2013;34:1059-65.
26. Balwinder K, Chittranjan V, Manjit M. Serum human chorionic gonadotropin level in preeclamptic and normotensive pregnant women: a prospective study. Int J Contemporary Med Res. 2017;4(8):1811-4.

27. Begum Z, Ara I, Tanira S, Keya Ka. The association between serum beta human chorionic gonadotropin and preeclampsia. J Dhaka Med Coll. 2014;23(1):8993

28. Aquilina J, Thompson O. Improved early prediction of preeclampsia by combining second trimester serum inhibin $A$ and uterine artery Doppler. Ultrasound Obstet Gynecol. 2001;17:477-84.

29. Crosignani PG, Trojsi L, Attanasio AE, Finzi GC. Value of HCG and HCS measurement in clinical practice. Obstet Gynecol. 1974;44:673-81.

30. Levine RJ, Lam C, Qian C, Yu KF, Maynard SE, Sachs BP et al. Soluble endoglin and other circulating antiangiogenic factors in preeclampsia. $\mathrm{N}$ Engl J Med. 2006;355:992-1005.

31. Maynard S, Epstein FH, Karumanchi SA. Preeclampsia and angiogenic imbalance. Annu Rev Med. 2008;59:61-78.

Cite this article as: Rathore N, Khajuria R, Jaggi R. $\beta$-hCG levels in second trimester as a predictor of gestational hypertension and preeclampsia. Int $\mathbf{J}$ Reprod Contracept Obstet Gynecol 2022;11:433-8. 